\title{
Table of secondary legislation
}

.eu Doman Name Regulation

Regulation (EC) 733/2002 of the

European Parliament and of the

Council of 22 April 2002 on the

implementation of the.eu Top

Level Domain [2002] OJ L113/1,

30 April 2002

Access Directive Directive 2002/

19/EC of 7 March 2002 of the

European Parliament and of the

Council on access to, and

interconnection of, electronic

communications networks and

associated facilities [2002] OJ

L108/7, 24 April 2002 ........ 31-32

Alternative Dispute Resolution

Directive (ADR Directive)

Directive 2013/11/EU of the

European Parliament and of the

Council of 21 May 2013 on

alternative dispute resolution for

consumer disputes and amending

Regulation (EC) 2006/2004 and

Directive 2009/22/EC [2013] OJ

L165/63, 18 June 2013 .. 107-108,

262

Attacks Against Information Systems

Directive Directive 2013/40/EU

of the European Parliament and of

the Council of 12 August 2013 on

attacks against information

systems [2013] OJ L218/8,

14 August 2013

342

Audiovisual Media Services Directive

(AVMSD) Directive 2010/

13/EU of the European Parliament

and of the Council of 10 March

2010 on the coordination of certain provisions laid down by law, regulation or administrative action in Member States concerning the provision of audiovisual media services (codified version) [2010] OJ L95/1, 15 April 2010 .... 29, 47, 122-126

Authorization Directive Directive 2002/20/EC of the European

Parliament and of the Council of 7 March 2002 on the authorization of electronic communications networks and services [2002] OJ

L108/21, 24 April 2002 31

Brussels I Regulation Council

Regulation (EC) 44/2001 of 22

December 2000 on jurisdiction and the recognition and enforcement of judgments in civil and commercial matters [2001] OJ L012/1, 16 January 2001 .... 76, 90

Brussels I Regulation (Recast) Regulation (EU) 1215/2012 of 12

December 2012 on jurisdiction and the recognition and enforcement of judgments in civil and commercial matters [2012] OJ L351/1, 20 December 2012 ..... 54, 75-77, 84, 88, 90-95, 101, 122, 130, 163, 167, 233, 239, 256, 261

Child Pornography Directive Directive 2011/92/EU of the European Parliament and of the Council of 13 December 2011 on combating the sexual abuse and sexual exploitation of children and child pornography, and replacing Council Framework Decision 2004/68/JHA [2011] OJ L26/1, 
17 December 2011 118,138 , 352-353

Collective Management of Copyright Directive Directive 2014/26/EU of the European Parliament and of the Council of 26 February 2014 on collective management of copyright and related rights and multi-territorial licensing of rights in musical works for online use in the internal market [2014] OJ L84/ 72, 20 March 2014 216-218

Conditional Access Directive Directive 98/84/EC of the European Parliament and of the Council of 20 November 1998 on the legal protection of services based on, or consisting of, conditional access [1998] OJ L320/54, 28 November 1998 196

Connected Continent Regulation Regulation (EU) 2015/2120 of the European Parliament and of the Council of 25 November 2015 laying down measures concerning open Internet access and amending Directive 2002/22/EC on universal service and users' rights relating to electronic communications networks and services and Regulation (EU) 531/2012 on roaming on public mobile communications networks within the Union [2015] OJ L310/1, 26 November 2015 32-35

Consumer Injunctions Directive

Directive 2009/22/EC of the European Parliament and of the Council of 23 April 2009 on injunctions for the protection of consumers' interests (codified version) [2009] OJ L110/30, 1 May 2009 108-109, 260-262

Consumer Rights Directive (CRD

Directive) Directive 2011/ 83/EC of 25 October 2011 of the European Parliament and of the
Council on consumer rights, amending Council Directive 93/ 13/EEC and Directive 1999/44/EC of the European Parliament and of the Council and repealing Council Directive 85/577/EEC and Directive 97/7/EC of the European Parliament and of the Council [2011] OJ L304/64, 22 November 2011 61-62, 230-234

Copyright Directive (InfoSoc

Directive) Directive 2001/ 29/EC of the European Parliament and of the Council of 22 May 2001 on the harmonization of certain aspects of copyright and related rights in the information society [2001] OJ L167/10, 22 June 2001 ........ 133, 153, 164, 175-200

Copyright Term Directive Directive 2011/77/EU of the European Parliament and of the Council of 27 September 2011 amending Directive 2006/116/EC on the term of protection of copyright and certain related rights [2011] OJ L265/1, 11 October 2011 ....... 177

Cybersecurity Directive (Also known as 'NIS Directive') Directive 2016/1148/EU of the European Parliament and of the Council concerning measures for a high common level of security of Network and Information Systems across the Union [2016] OJ C218/1, 16 June 2016 .... 347-349

Data Protection Directive Directive 95/46/EC of the European Parliament and the Council of 24 October 1995 on the protection of individuals with regard to the processing of personal data and on the free movement of such data [1995] OJ L281/31, 23 November 1995 268, 269-282, 304

Data Retention Directive Directive 2006/24/EC of 15 March 2006 of the European Parliament and of 
the Council on the retention of data generated or processed in communication with the provision of publicly available electronic communications services or of public communication networks and amending Directive 2002/ 58/EC [2006] OJ L105/54, 13 April 2006 165, 296-299

Database Directive Directive 96/9/EC of the European Parliament and of the Council of 11 March 1996 on the legal protection of databases [1996] OJ L77/20, 27 March 1996 $175,177,210-211$

Design Regulation Council

Regulation (EC) 6/2002 of 12

December 2001 on Community

Designs [2001] OJ L3/1, 12

December 2001 82

Distance Marketing of Consumer

Financial Services

Directive Directive 2002/65/EC of the European Parliament and of the Council of 23 September 2002 concerning the distance marketing of consumer financial services, amending Directives 97/7/EC and 98/27/EC [2002] OJ L271/16, 9 October 2002 ......... 239-241, 248

Distance Selling Directive Directive 97/7/EC of the European

Parliament and of the Council of 20 May 1997 on the protection of consumers in respect of distance contracts [1997] OJ L144/19, 4 June 1997 .. 52, 230, 239, 248, 253

Doorstep Selling Directive Council Directive 85/577/EEC of 20

December to protect the consumer in respect of contracts negotiated away from business premises [1985] OJ L372/31, 31 December 1985 230

Electronic Commerce Directive

Directive 2000/31/EC of the European Parliament and of the Council of 8 June 2000 on certain legal aspects of information society services, in particular electronic commerce, in the internal market [2000] OJ L178/1, 17 July 2000 .... 15, 38-60, 40, 43, 59, 104, 151-163, 186, 253, 341,354

E-Identification and Trust Regulation (eIDAS Regulation) Regulation (EU) 910/2014 of the European Parliament and of the Council of 23 July 2014 on electronic identification and trust services for electronic transactions in the internal market and repealing Directive 1999/93/EC [2014] OJ L257/73, 28 August 2014 310

E-Money Directive Directive 2009/ 110/EC of the European Parliament and of the Council of 16 September 2009 on the taking up, pursuit and prudential supervision of the business of electronic money institutions, amending Directives 2005/60/EC and 2006/48/EC and repealing Directive 2000/46/EC [2009] OJ L267/7, 10 October 2009 $53,321-325$

E-Privacy Directive (Directive on Privacy and Electronic Communications) Directive 2002/58/EC of 12 July 2002 of the European Parliament and of the Council concerning the processing of personal data and the protection of privacy in the electronic communications sector [2002] OJ L201/37, 31 July 2002, amended by Directive 2009/136/EC [2009] OJ L337/11, 18 November 2009 265, 280, 299-306

E-Signatures Directive Directive 1999/93/EC of the European Parliament and of the Council of 13 December 1999 on a Community framework for 
electronic signatures [2000] OJ

L13/12, 19 January 2000 ........ 310

First Amending Directive

(Telecoms) Directive 2009/

136/EC of 25 November 2009

amending Directive 2002/22/EC

on universal service and users'

rights relating to electronic

communications networks and

services, Directive 2002/58/EC

concerning the processing of

personal data and the protection of

privacy in the electronic

communications sector and

Regulation (EC) 2006/2004 on

cooperation between national

authorities responsible for the

enforcement of consumer

protection laws [2009] OJ L337/

11, 18 December 2009 ..... 31, 268

Framework Directive Directive 2002/

21/EC of 7 March 2002 on a

common regulatory framework for

electronic communications

networks and services [2002] OJ

L108/33, 24 April 2002 ..... 29-32,

$35,69,296$

General Data Protection Regulation

(GDPR) Regulation (EU) 679/

2016 of the European Parliament

and of the Council of 27 April

2016 on the protection of natural

persons with regard to the

processing of personal data and on

the free movement of such data, and repealing Directive 95/46/EC [2016] OJ L1 19/1, 4 May 2016 $282-292$

Human Trafficking

Directive Directive 2011/36/EU of the European Parliament and of the Council of 5 April 2011 on preventing and combating trafficking in human beings and protecting its victims, and replacing Council Framework
Decision 2002/629/JHA [2011]

OJ L101/1, 15 April 2011 ...... 138,

Intellectual Property Rights

Enforcement Directive (IPRE

Directive) Directive 2004/

48/EC of the European Parliament and of the Council of 29 April

2004 on the enforcement of intellectual property rights [2004]

OJ L195/16, 2 June 2004 ....... 133,

$164,200-208$

Mediation Directive Directive 2008/

52/EC of the European Parliament and of the Council of 21 May 2008 on certain aspects of mediation in civil and commercial matters [2008] OJ L136/3, 24 May 2008 108,262

Misleading Advertising

Directive Directive 2006/114 of the European Parliament and of the Council of 12 December 2006 on misleading and comparative advertising [2006] OJ L376/21, 27

December 2006 .............. 246-248

Online Dispute Resolution

Regulation Regulation(EU)

524/2013 of the European

Parliament and of the Council of

21 May 2013 on online dispute resolution for consumer disputes and amending Regulation (EC)

2006/2004 and Directive 2009/

22/EC [2013] OJ L165/1, 18 June

2013 109,262

Orphan Works Directive Directive

2012/28/EU of the European

Parliament and of the Council of

25 October 2012 on certain

permitted uses of orphan works

[2012] OJ L299/5, 27 October

2012 218-219

Payment Services Directive (2)

Directive 2015/2366/EU of the

European Parliament and of the Council of 25 November 2015 on payment services in the internal 
market, amending Directives 2002/65/EC, 2009/110/EC and 2013/36/EU and Regulation (EU) 1093/2010, and repealing Directive 2007/64/EC [2015] OJ L337/35, 23 December 2015 ...... 241, 242-244, 322-327

Police and Criminal Justice Authorities

Directive Directive 2016/ 680/EU of the European Parliament and of the Council of 27 April 2016 on the protection of natural persons with regard to the processing of personal data by competent authorities for the purposes of the prevention, investigation, detection or prosecution of criminal offences or the execution of criminal penalties, and on the free movement of such data, and repealing Council Framework Decision 2008/977/JHA [2016] OJ L119/89, 4 May 2016 ....... 268, 288

Rental and Lending Rights Directive (original version) Directive 92/100/EEC of 19 November 1992 on rental right and lending right and on certain rights related to copyright in the field of intellectual property [1992] OJ L346/61, 27 November 1992 175

Rental and Lending Rights Directive (codified) Directive 2006/ 115/EC of the European Parliament and of the Council of 12 December 2006 on rental right and lending right and on certain rights related to copyright in the field of intellectual property (codified version) [2006] OJ L376/28, 27 December 2006 .. 177 Rome I Regulation Regulation (EC) 593/2008 of the European Parliament and of the Council of 17 June 2008 on the law applicable to contractual obligations [2008] OJ L177/6, 4 July 2008 ..... 75, 79, 93-96, 108, 239, 260-261

Rome II Regulation Regulation (EC) 864/2007 of the European Parliament and of the Council of 11 July 2007 on the law applicable to non-contractual obligations [2007] OJ L199/40, 31 July 2007 74-75, 93, 96-99, 130

Sales and Guarantees Directive Directive 1999/44/EC of the European Parliament and of the Council of 25 May 1999 on certain aspects of the sale of consumer goods and associated guarantees [1999] OJ L171/12, 7 July 1999 65

Satellite and Cable Broadcasting

Directive Council Directive 93/ 83/EEC of 27 September 1993 on the coordination of certain rules concerning copyright and rights related to copyright applicable to satellite broadcasting and cable retransmission [1993] OJ L248/ 15, 6 October 1993

Second Amending Directive

(Telecoms) Directive 2009/ 140/EC of 25 November 2009 amending Directive 2002/21/EC on a common regulatory framework for electronic communications networks and services, Directive 2002/19/EC on access to, and interconnection of, electronic communications networks and associated facilities, and Directive 2002/20/EC on the authorization of electronic communications networks and services [2009] OJ L337/37, 18

December 2009 31,34

Services Directive Directive 2006/ 123/EC of the European Parliament and of the Council of 12 December 2006 on services in the internal market [2006] OJ 
L376/36, 27 December 2006 $220,231,237$

Software Directive (original version) Council Directive 91/ 250/EEC of 14 May 1991 on the legal protection of computer programs [1991] OJ L122/42, 17 May 1991 $175,201,211$

Software Directive (codified)

Directive 2009/24/EC of the

European Parliament and of the Council of 23 April 2009 on the legal protection of computer programs (codified version) [2009] OJ L111/16, 5 May 2009 $177,201,211-213$

Technical Standards

Directive Directive 98/34/EC of the European Parliament and of the Council of 22 June 1998 laying down a procedure for the provision of information in the field of technical standards and regulations and on rules on information society services [1998] OJ L204/37, 21 July 1998 46,152

Telecommunications Privacy Directive (ISDN Directive) Directive 97/ 66/EC of the European Parliament and of the Council of 15 December 1997 concerning the processing of personal data and the protection of privacy in the telecommunications sector [1997] OJ L24/1, 15

December 1997 253,305

Trademark Directive Directive 2015/ 2436/EU of the European Parliament and of the Council of 16 December 2015 to approximate the laws of the Member States relating to trademarks [2015] OJ L336/1, 23 December 2015 213-216

Trademark Regulation Regulation (EU) 2424/2015 of the European Parliament and of the Council of
16 December 2015 amending Council Regulation (EC) 207/ 2009 on the Community trademark and Commission Regulation (EC) 2868/95 implementing Council Regulation (EC) 40/94 on the Community trademark, and repealing Commission Regulation (EC) $2869 / 95$ on the fees payable to the Office for Harmonization in the Internal Market (Trade Marks and Designs) [2015] OJ L341/21, 24

December 2015 213-216

Trade Secrets Directive Directive 2016/943/EU of the European Parliament and of the Council of 8 June 2016 on the protection of undisclosed know-how and business information (trade secrets) against their unlawful acquisition, use and disclosure [2016] OJ L157/1, 15 June 2016 270

Unfair Commercial Practices Directive

(UCP Directive) Directive 2005/29/EC of the European Parliament and of the Council of 11 May 2005 concerning unfair business-to-consumer commercial practices in the internal market and amending Council Directive 84/ 450/EEC, Directive 97/7/EC, Directive 98/27/EC and Directive 2002/65/EC of the European Parliament and of the Council and Regulation (EC) 2006/2004 of the European Parliament and of the Council [2005] OJ L149/22, 11 June 2005 ......... 44, 231, 247-251

Unfair Terms in Consumer Contracts Directive Directive 93/13/EEC of 5 April 1993 on unfair terms in consumer contracts [1993] OJ L95/29, 21 April 1993 ............ 91, 106-107, 230, 234-237, 255 
Universal Service Directive Directive 2002/22/EC of the European

Parliament and of the Council of 7 March 2002 on universal service and users' rights relating to electronic communications networks and services [2002] OJ L108/51, 24 April 2002 35 